\title{
Prospek Kebijakan dalam Pembangunan Hukum Nasional Barbasis Partisipasi Masyarakat pada Era 4.0
}

\author{
Fatkhul Muin \\ Fakultas Hukum Universitas Sultan Ageng Tirtayasa Serang Banten \\ fatkhulmuin@untirta.ac.id \\ Pipih Ludia Karsa \\ Fakultas Hukum Universitas Sultan Ageng Tirtayasa Serang Banten \\ pipihludiakarsa@ymail.com
}

DOI : 10.23917/jjr.v9i1.8094

Submission
Track:
Received:
1 Mei 2019
Final Revision:
15 Juni 2019
Available online:
30 Juni 2019
Corresponding
Author:
Fatkhul Muin
fatkhulmuin@untirta.ac.id

\section{ABSTRACT}

Tujuan: Artikel ini bertujuan untuk (1) mengkaji paradigma pembangunan hukum dalam kerangka tujuan negara era industry dan (2) mengelaborasi pembangunan hukum nasional dan partisipasi masyarakat di Era 4.0

Metodologi: Tulisan ini menggunakan metodologi penelitian kualitatif dengan pendekatan yuridis normatif melalui studi pustaka secara menyeluruh (holistic).

Temuan: Dalam memahami pembangunan hukum, dapat melalui dimensi regulasi dan turunan-turunan regulasi, dimana tinjauan utama pada 3 (tiga) persepktif utama pada konsideran, yaitu pada aspek filosofis, aspek sosiologis dan aspek yuridis. Ketiga hal tersebut dapat menjadi landasan dalam pembangunan hukum nasional dengan melibatkan masyarakat secara langsung dalam penentuan kebijakan hukum.

Kegunaan: Kebijakan sistem pembangunan nasional harus mengatur tentang partisipasi masyarakat dalam industry 4.0 sehingga peran tersebut tidak hanya dijalanan oleh negara.

Kebaruan/Orisinalitas: Dalam Era Industri 4.0, peran pembangunan dalam sistem pembangunan nasional tidak hanya bertempu pada negara yang memiliki alat kewenangan, tapi masyarakat juga harus berpartisipasi penuh dalam sistem pembangunan nasional.

Keywords: Pembangunan, Hukum, Partisipasi dan Masyarakat 


\section{PENDAHULUAN}

Pembangunan nasional dalam kerangka konseptual tertuju kepada kepentingan bangsa dan negara yang secara khusus berdimensi kepada nilia-nilai kesejahteraan ${ }^{1}$ yang dibangun melalui berbagai kebijakan yang disusun oleh pemerintah. Termonologi dasar dalam pembangunan sering menjadi isu utama dan arus utama dalam berbagai segmentasi kehidupan berbangsa dan kehidupan bernegara. Contoh konkrit dalam hal ini dapat ditinjau melalui pandangan-pandangan masyarakat pada seluruh lapisan masyarakat dalam memberikan pandangan terhadap pembangunan pada umumnya.

Paradigama pembangunan sendiri didalam kehidupan bernegara diletakan dalam dimensi dasar, baik itu melalui prinsip dasar ideologi atau melalui kerangka konstitusional dan regulasi yang dibawahnya sebagai aturan pelaksana dari struktur susunan hukum yang ada di Indonesia. Pencanangan pembangunan nasional sebagai kerangka pencapiana keadilan yang bersifat substantif berada pada sisi society (kemasyarakatan), dimana dalam hal ini bahwa keadilan sosial sebagai landasan utama yang termuat dalam Pancasila dan Konstitusi harus diejawantahkan dalam dimensi kehidupan bernegara dan dirasakan secara langsung oleh masyarakat, bahwa pembangunan pada hakikatnya berkorelasi secara struktur dengan hakikat kesejahteraan sosial.

Pemikiran dasar dan kerangka pembangunan tidak terlepas dari peran serta aktif masyarakat, ${ }^{2}$ sebagai landasan berfikir diawal, tentu kita dapat menarik sauatu analisis dasar

\footnotetext{
${ }^{1}$ Landasan dalam suatu gagasan pada hakikatnya bahwa kesejahteraan sosial merupakan salah satu sebagai tujuan akhir dari kegiatan pembangunan nasional yang dicanangkan oleh pemerintah, oleh karena itu, ada suatu pra kondisi sebagai upaya untuk menentukan pencapaian kesejhateraan sosial. Pada dasarnya Kualitas sumber daya manusia dan pemenuhan kebutuhan sosial dasar untuk setiap warga negaralah yang merupakan pra kondisi menuju kepada kesjehateraan sosial. Oleh Karena itu, dalam rangka mewujudkan hakikat dari kesejahteraan sosial ataupun pada tata kehidupan sejahtera bagi setiap warga negara, kondisi tersebut harus diselesaikan terlebih dahulu secara simultan dan tuntas sehingga tercapai apa yang menjadi tujuan dasar dalam pembangunan tersebut menuju kesejahteraan sosial. Lihat Suradi, Pembangunan Manusia, Kemiskinan Dan Kesejahteraan Sosial Kajian tentang Kebijakan Pembangunan Kesejahteraan Sosial di Nusa Tenggara Barat, Jurnal Penelitian dan Pengembangan Kesejahteraan Sosial, Vol 12, No. 03, 2007, hlm. 2

${ }^{2}$ Konstitusi Negara secara jelas mengarah kepada lahirnya tujuan pembangunan suatu Negara dilaksanakan merupakan untuk melahirkan kesejahteraan bagi masyarakat, maka hal tersebut sama dengan disusunya konstitusi Negara Indoensia yang bertujuan untuk memberikan kesejahteraan kepada masyarakat. dimesi utama dalam Pembukaan Undang-Undang Dasar 1945, dinyatakan bahwa hakikat dari tujuan Pembangunan Nasional Bangsa Indonesia "melindungi segenap bangsa dan seluruh tumpah darah Indonesia, memajukan kesejahteraan umum, mencerdaskan kehidupan bangsa, serta ikut melaksanakan ketertiban dunia". Oleh karena itu, dalam rangka untuk mewujudkan tujuan tersebut dilaksanakan pembangunan nasional yang tersusun dan terstruktur, yaitu dalam kerangka pembangunan manusia Indonesia seutuhnya dan pembangunan masyarakat seluruhnya dan pembangunan pada seluruh aspek kehidupan masyarakat Indonesia agar menjadi masyarakat yang sejahtera adail dan makmur berdasarkan cita-cita bangsa Indonesia. Lihat Melis, et.al. Analisis Partisipasi Masyarakat Dalam Pembangunan Desa (Studi Di Desa Wawolesea Kecamatan Lasolo Kabupaten Konawe Utara), Jurnal Ekonomi (JE) Vol (1), 2016, hlm. 99.
} 
dalam memberikan makna partisipasi masyarakat dalam pembangunan, yang salah satunya berada dalam pembangunan hukum pada era industri saat ini. Industrialisasi pada seluruh sektor bahkan pada aspek jasa, diperlukan adanya regulasi yang berdimensi kepada kepentingan pada 2 (dua) sisi, yaitu pada kepentingan masyarakat dan pada kepentingan industri, sehingga arti sinergi mencapai pada titik keadilan dalam pembangunan nasional dan memberikan nilai kesejahteraan bagi masyarakat pada umumya.

\section{METODOLOGI PENELITIAN}

Penelitian yang mengkaji tentang "Prospek Kebijakan dalam Pembangunan Hukum Nasional Barbasis Partisipasi Masyarakat Pada Era 4.0, ini menggunakan jenis penelitian kualitatif dengan pendekatan yuridis normatif melalui studi pustaka secara menyeluruh (holistic). Sumber data dalam penelitian ini, terdiri dari bahan hukum primer, bahan hukum sekunder, dan bahan hukum tersier. Adapun teknik analisis data dengan mengolah hasil pengumpulan bahan primer, serta pengumpulan bahan sekunder untuk dilanjutkan dengan menganalisis secara menyeluruh, terhadap peraturan perundang-undangan, literatur, data, dan beberapa dokumen yang terkait, serta bahan hukum tersier untuk menjelaskan dan membantu dalam menganalisis bahan hukum primer maupun sekunder.

\section{PEMBAHASAN}

\section{Paradigma Pembangunan Hukum dalam Kerangka Tujuan Negara Era Industri}

Postulat dasar yang sering menjadi bahan kajian dalam hukum adalah bahwa hukum menjadi alat untuk meciptakan kesejahteraan bagi masyarakat. Perkembangan hukum tentu berbanding lurus dengan kepentingan masyarakat pada umumnya,dimana dalam dialektika perkembangan hukum bahwa delegasi kewenangan yang lahir dan menjadi bahan bagi setiap orang untuk melaksanakan kewajibannya sebagai subjek hukum itu sendiri. Dalam arti yang bersifat konkrit, regulasi yang dibentuk oleh badan-badan Negara yang memiliki kewenangan secara normative untuk pembentukan peraturan perundang-undangan, tentu lembaga tersebut harus melahirkan suatu produk hukum yang bersifat aspiratif.

Dalam era moderen saat ini, dengan masuknya pada era 4.0, dimana kekuatan arus globalisasi terhadap semua aspek telah berjalan. Oleh karena itu dengan adanya era tersebut 
diatas, maka diperukan suatu sistem hukum yang bersifat responsif terhadap perkembangan era dan tentu perkembangan era sangat dipengaruhi dengan perkembangan masyarakat, dimana secara substantif, bahwa masyarakat dalam dimensi sosial ikut memberikan pengaruh terhadap perkembangan hukum pada era 4.0 saat ini.

Orientasi yang perlu dibangun dengan adanya perkeembangan dalam berbagai aspek adalah hukum yang tidak bersifat statis. Dengan berkembangnya hukum dan masyarakat dalam era saat ini, tentu akan memberikan suatu nilai manfaat dan kepastian hukum bagi masyarakat dan tidak melahirkan konflik dalam kehidupan masyarakat, karena hukum memberikan rasa keadilan bagi masyarakat dan memberikan kesejahteraan bagi masyarakat, sehingga melahirkan masyarakat madani (civil society), yang mengarah kepada kesejahteraan dengan berlandaskan kepada 3 (tiga) aspek utama, sebagai berikut:

\section{Bagan I}

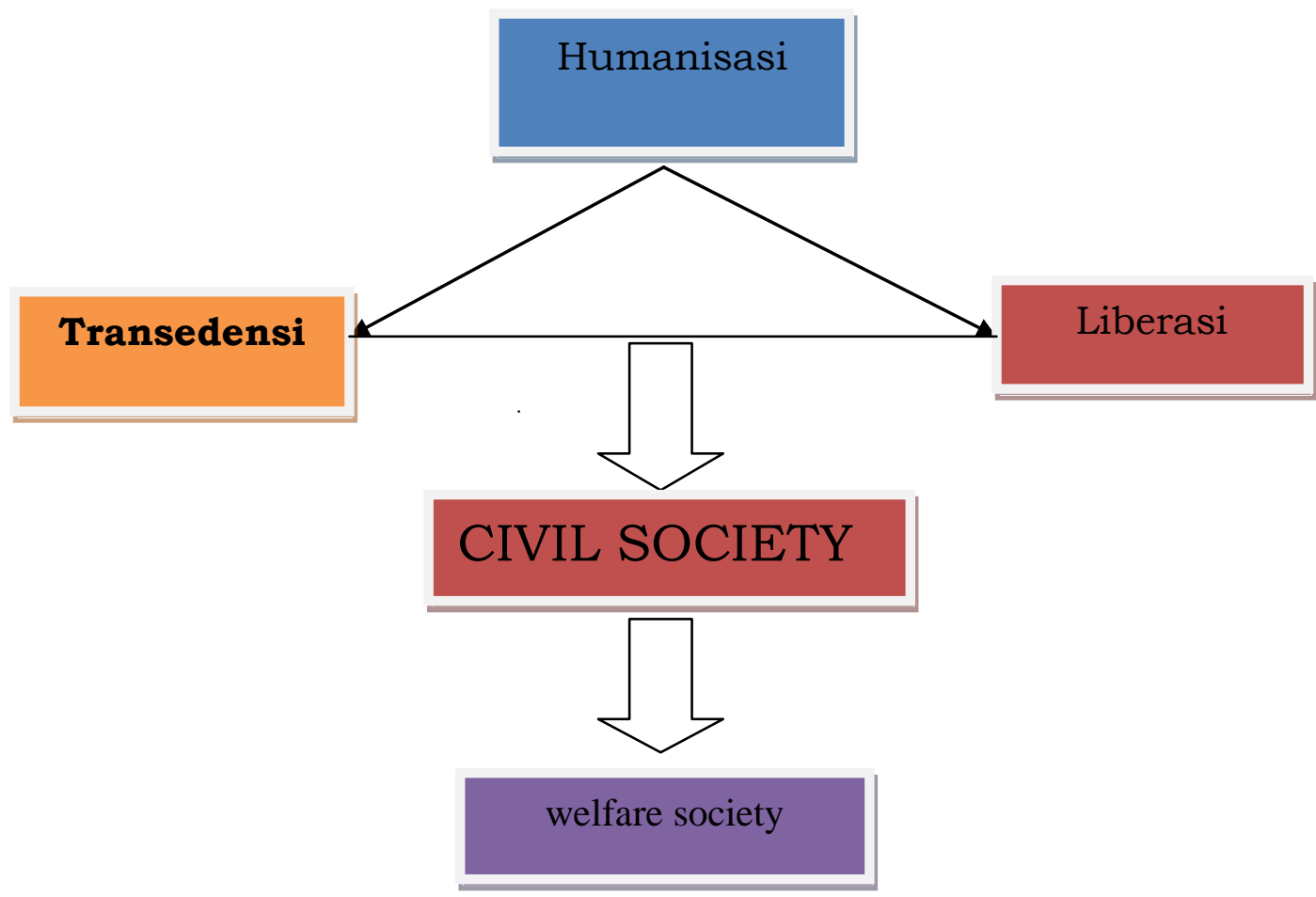

Arus baru dalam dimesi pembangunan hukum nasional tentu tidak boleh lepas dari dimensi patron Humanisasi, liberasi dan transedensi, dimana dalam hakikat pembangunan hukum di Indonesia dilegitimasi ketiganya dalam Pancasila sebagai penguat dan ciri KeIndonesiaan. Gagasan yang lahir dari Pancasila dijadikan dasar dalam rangka melahirkan suatu tatanan hukum Indonesia berbasis kepada welfare society, dimana posisi kepentingan 
masyarakat menjadi suatu argumentasi dasar dalam rangka melahirkan keadilan bagi masyarakat sebagai mana tertuang dalam Pancasila dalam dimensi "Keadilan Sosial bagi Seluruh Rakyat Indonesia”.

Asumsi dasar pada tahap perencanaan pembanguna diperlukan dalam aspek regulasi dengan menelusur melalui akar regulasi yang dapat memberikan aspek pengaruh dalam sisi pembangunan. Secara sederhana dapat dimulai dengan suatu pemikiran sebagai berikut:

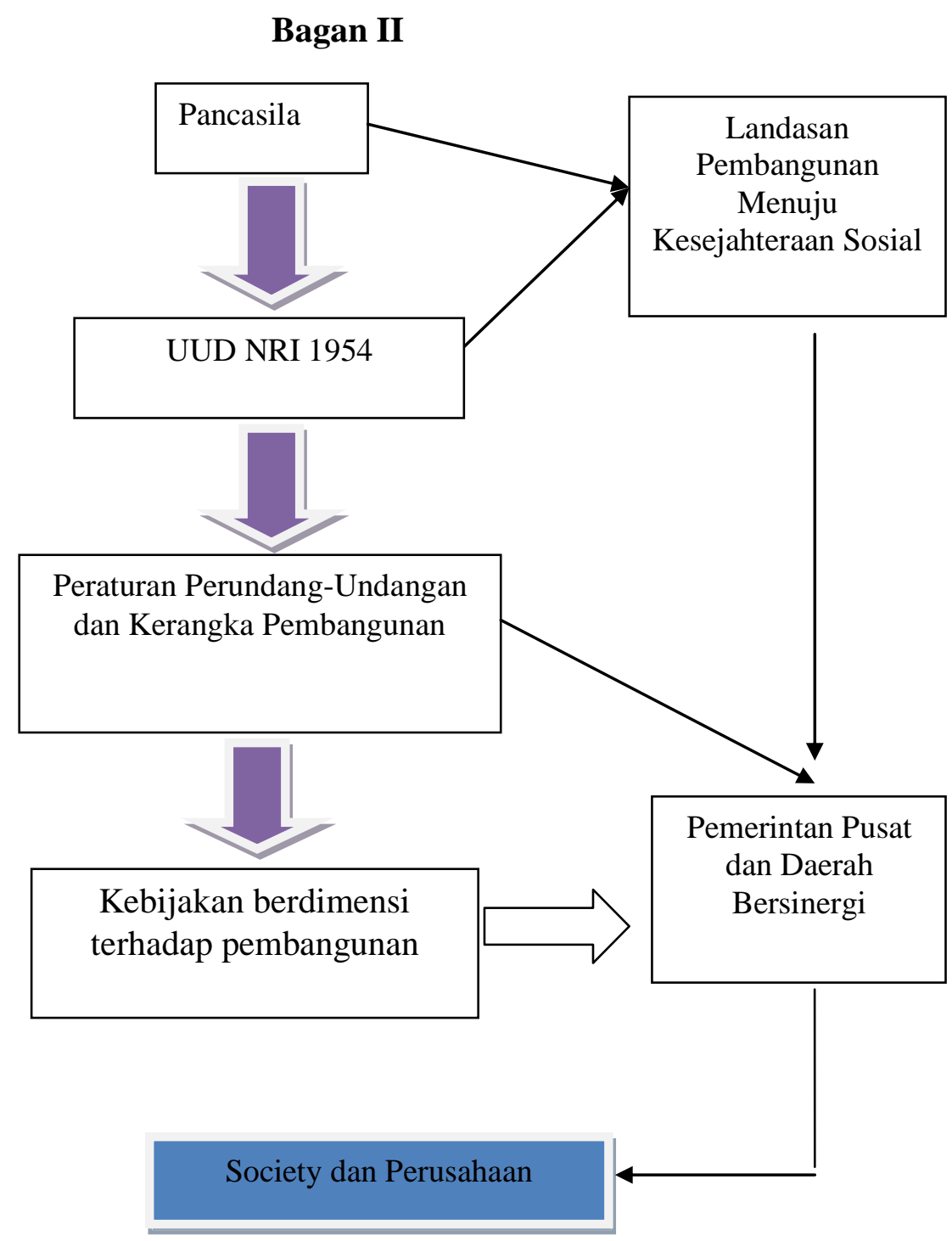

Kerangka dasar tersebut diatas sebagai suatu pijakan dalam persepektif pembangunan nasional dengan dimulai dari sisi hukum sebagai landasan dalam pembangunan nasional. 


\section{Pembangunan Hukum Nasional dan Partisipasi Masyarakat di Era 4.0}

Sebagai gelaja sosial, hukum dimaksud untuk menciptakan dan mengusahakan adanya keseimbangan diantara ragam kepentingan yang terdapat dalam masyarakat, sehingga konflik kepentingan antar anggota masyarakat dapat dihindari. Kendati demikian, jika konflik tersebut ternyata terjadi, hukum digunakan sebagai instrument untuk proses penyelesaiannya. Oleh karena itu, agar proses pemenuhan kepentingan masing-masing manusia yang ada dalam komunitas masyarakat untuk tidak berpeluang menimbulkan konflik, maka diperlukan adanya aturan yang mengatur hak dan kewajiban masing-masing pihak dalam mengadakan kontak atau hubungan diantara sesamanya. Aturan itu ialah hukum. Ketika hukum menjadi norma, maka mempunyai cirri kekhususan yaitu hendak melindungi, mengatur dan memberikan keseimbangan dalam menjaga kepentingan umum. ${ }^{3}$

Ketika era telah beralih, peralihan tersebut akan berdampak pada sisi pandang dalam memahami konsepsi hukum sebagai bagian dari suatu evaluasi, terutama pada pemahaman masyarakat dari mulai keterlibatan atau partisipasi sampai dengan penegakkan hukum secara komprehensip, walaupun makna komprehensif ini masih dalam tataran yang berkembang, dan itu akan mengalami suatu perubahan indikasi terhadap pembangunan hukum Indonesia, terutama pada aspek kebutuhan hukum yang bersinergi antara industri, masyarakat dan hukum. Kemajuan industri akan berkolerasi dengan teknologi, dan teknologi akan berkolerasi dengan kebutuhan Sumber Daya Manusia maupun Sumber Daya lainnya. Hal tersebut merupakan bagian dari dinamika perkembangan industri yang akan berdampak terhadap kebutuhan hukumnya. Pertanyaan akan mucul diantaranya adalah, apakah kemajuan teknologi akan menjadi bagian dalam pembangunan hukum nasional? Namun perkembangan tersebut tidak dapat terlepas dari nilai-nilai moralitas ${ }^{4}$ yang wajib menjadi bagian dalam pembangunan hukum nasional, walaupun era telah beralih, dan pembangunan terus mengalir.

\footnotetext{
${ }^{3}$ Najih, Mokhammad dan Soimin, Pengantar Hukum Indonesia: Sejarah, Konsep Tata Hukum dan Politik Hukum Indonesia, Malang: Setara Press, 2012, hlm.2.

${ }^{4}$ Kaitan hukum dan moralitas dalam pemikiran Hart memang tidak sederhana. Dibanyak bagian dalam The concept of law dan tulisan Hart lainnya, hubungan keduanya (Hukum dan Moral) diuraikan sedemikian rupa sehingga menghalangi setiap godaan untuk melabelinya sebagai pemikir hukum yang menyangkal moralitas. Pertama, Hart mengakui bahwa meskipun hukum dan moralitas itu berbeda, tapi dalam beberapa hal penting memiliki kesamaan. Kesamaan itu misalnya, keduanya memiliki isi yang sama, yaitu larangan membunuh dan mencampuri hak milik orang lain, sehingga keduanya dianggap sebagai sesuatu hal yang penting dalam menjaga tatanan sosial. Kedua, hubungan penting antara hukum dan moralitas terlihat dari beberapa pernyataan berikut:

1. Bahwa faktanya hukum mewujudkan cita-cita moral;

2. Moralitas dan hukum memiliki hubungan interdependen;

3. Hukum harus mewujudkan nilai-nilai moral;
} 
Pembangunan yang dilakukan oleh suatu bangsa harus memihak kepada kepentingan rakyat. Pembangunan sebagai suatu proses yang berkesinambungan harus senantiasa tanggap dan peka terhadap dinamika yang terjadi di dalam masyarakat, baik di bidang politik, ekonomi, teknologi, sosial dan budaya dan sebagainya. Masyarakat modern (modern society) hidup dalam era teknologi informasi (information technology) atau disebut juga dengan informative society yang saat ini populer disebut dengan "disruptive era" atau era revolusi industri 4.0. Artinya, dunia global telah menempatkan kehidupan manusia berada di tengah-tengah arus teknologi yang begitu cepat perkembangannya dan sekaligus menjadi ancaman bagi manusia. Kemajuan dalam bidang teknologi (informasi) merupakan hasil karya intelektual manusia yang telah banyak membawa perubahan luar biasa dalam pola hidup manusia dewasa ini.

Berbagai capaian manusia dalam bidang paten dan hak cipta merupakan bukti nyata, bahwa dalam perdagangan dunia karya-karya intelektual manusia telah menjadi mesin ekonomi yang sangat ampuh bagi pertumbuhan ekonomi suatu bangsa. Dalam konteks itulah sangat tepat dikatakan, bahwa teori keuntungan (benefit theory) dalam perlindungan hukum atas hak milik intelektual (intellectual property rights) sangat relevan, karena perlombaan untuk menghasilkan karya-karya intelektual dilakukan untuk mendapatkan keuntungan (materil dan moril) bagi si pencipta atau inventor.

Perubahan yang begitu cepat dalam dunia bisnis merupakan ciri dari kehidupan manusia di era disruption. Kehidupan dunia usaha dan bisnis yang didukung oleh teknologi informasi, seperti internet telah menciptakan dunia bisnis seolah-olah tanpa batas (borderless trade) di seluruh penjuru dunia. Kemajuan ini secara otomatis, baik langsung maupun tidak langsung, telah berimplikasi pada eksistensi hukum yang mengaturnya. Kemajuan pesat yang terjadi dalam masyarakat dunia, termasuk juga masyarakat Indonesia, perlu diikuti dengan sentuhan hukum, sehingga eksistensi negara hukum dapat terus dipertahankan. Artinya dukungan yang diberikan oleh pemerintah dalam pengembangan teknologi informasi harus diikuti dengan perkembangan hukum, sehingga kemajuan teknologi tersebut dapat bermanfaat

4. Hukum secara definisi, mewujudkan moralitas;

5. Dari fakta tentang hakikat manusia dan dunia, dimana mereka hidup, aturan hukum dan moralitas memiliki isi minimum yang sama.

Bello, Petrus CKL, Hukum dan Moralitas, Tinjauan Filsafat Hukum, Jakarta: Erlangga PT. Gelora, Aksara Pratama, 2012, hlm. 4-5. 
secara maksimal bagi masyarakat dan negara dan akan dapat mendorong masuknya investor ke Indonesia.

Perkembangan dan kemajuan teknologi informasi secara global membawa dampak luas di tengah-tengah kehidupan masyarakat nasional dan internasional. Kemajuan tersebut tidak hanya telah menciptakan perdagangan dengan menggunakan elektronik (electronic commerce-e-commerce), sehingga telah melenyapkan konsep jual beli secara konvensional, tetapi sekaligus juga telah menimbulkan kekhawatiran dan ketakutan masyarakat terhadap ekses-ekses negatif dari teknologi tersebut, seperti kejahatan terhadap credit card atau Anjung Tunai Mandiri (ATM) serta ancaman keadidayaan teknologi informasi sebagai pengganti tenaga manusia di dalam dunia kerja seperti maraknya online shopping. ${ }^{5}$

Jika ditinjau dari aspek sejarah dan istilah Revolusi Industri pertama kali dikemukakan oleh Arnold Toynbee dalam bukunya Lectures On the Indutrial Revolution. Revolusi Industri 1.0, Diawali dengan penemuan mesin uap oleh James Watt. Revolusi Industri 2.0 dengan penemuan listrik, dan Revolusi Industri 3.0 dengan penemuan komputer. Revolusi Industri 4.0 ditandai pada awal abad ke-21, ditandai dengan penemuan Internet dan Teknologi Informasi (TI) memicu kelahiran. Sebagai konsekuensi penemuan-penemuan baru tersebut, tentunya akan memiliki dampak dengan ditandai cirri-ciri yang berbeda, dari mulai 1.0 sampai dengan 4.0 dalam penerapannya, diantaranya yang telah disampaikan oleh John Pieris. ${ }^{6}$ Dari perkembangan tersebut, satu sisi merupakan bagian dari peradaban baru, sisi lain merupakan suatu lahirnya konsekuensi dampak dari peradaban baru tersebut sehingga Negara harus hadir dalam perkembangan peradaban tersebut guna merespons Revolusi 4.0. misalnya terkait dengan penegakan hukum dan produk hukum yang akan dibentuk, kemudia revolusi industri selalu memicu perubahan kapital, teknologi dan labor atau ketenagakerjaan. Revolusi Industri 4.0 dapat memengaruhi peraturan tentang hak cipta, merk dagang, dan kontrak. Hukum harus dapat merespons perubahan, keingingan, dan kebutuhan masyarakat ini (responsive law). Namun, aspek fundamental hukum yakni etika, moral, dan norma atau kaidah hukum harus

\footnotetext{
${ }^{5}$ https://uir.ac.id/opini_dosen/tantangan-hukum-di-era-revolusi-industri-4-0-oleh-syafrinaldi, (Akses 30 Maret 2019.

${ }^{6}$ John Pieris menyebutkan dampak atau ciri tersebut yakni: (1) simple atau sederhana dan anti rumit; dulu jika bermain game, hanya satu alat dan satu game; kini melalui teknologi Anroid, satu alat untuk ribuan bahkan jutaan games; (2) cepat (faster), kapan saja, dan dari mana saja di antar negara; Dahulu, kalau ingin lulus di Universitas di Amerika misal Harvard University harus pergi ke Amerika Serikat. Sekarang, daftar bisa via webnya; (3) lebih murah (cheaper), dan (4) mudah diakses (accessible); akses adalah kekayaan informasi. Lihat Pieris, John, Kecerdasan Hukum Respons Revolusi Industri 4.0, http://www.stagingpoint.com/read/2018/11/14/151205/Kecerdasan.Hukum. Respons.Revolusi.Industri.4.0. (Akses 30 Maret 2019).
} 
tetap dipertahankan oleh Negara, Rakyat dan Pemerintah. Sedangkan peraturan dan regulasi memiliki fleksibilitas guna merespons perubahan dan peradaban baru. ${ }^{7}$ Sehingga, dalam perkembangan industri tersebut masyarakat dituntut untuk menyesuaikan secara cepat, termasuk pembentukan hukum nasional yang tidak saja memenuhi kebutuhan masyarakat, tetapi juga kebutuhan industri.

\section{PENUTUP}

Partisipasi masyarakat dalam pembangunan, salah satunya berada dalam pembangunan hukum pada era industri saat ini. Industrialisasi pada seluruh sektor bahkan pada aspek jasa, diperlukan adanya regulasi yang berdimensi kepada kepentingan pada 2 (dua) sisi, yaitu pada kepentingan masyarakat dan pada kepentingan industri.Dalam era moderen saat ini, dengan masuknya pada era 4.0, dimana kekuatan arus globalisasi terhadap semua aspek telah berjalan. Oleh karena itu dengan adanya era tersebut diatas, maka diperlukan suatu sistem hukum yang bersifat responsif terhadap perkembangan era dan tentu perkembangan era sangat dipengaruhi dengan perkembangan masyarakat, secara substantif, bahwa masyarakat dalam dimensi sosial ikut memberikan pengaruh terhadap perkembangan hukum pada era 4.0 saat ini. Kemajuan pesat yang terjadi dalam masyarakat dunia, termasuk juga masyarakat Indonesia, perlu diikuti dengan sentuhan hukum, sehingga eksistensi negara hukum dapat terus dipertahankan dalam perkembangan industri tersebut. Masyarakat dituntut untuk menyesuaikan secara cepat, termasuk pembentukan hukum nasional baik yang berbasis pada partisipasi masyarakat maupun insdustri.

\section{REFERENCES}

Bello, Petrus CKL, Hukum dan Moralitas, Tinjauan Filsafat Hukum, Jakarta: Erlangga, PT. Gelora, Aksara Pratama, 2012.

Melis, et.al. Analisis Partisipasi Masyarakat Dalam Pembangunan Desa (Studi Di Desa Wawolesea Kecamatan Lasolo Kabupaten Konawe Utara), Jurnal Ekonomi (JE) Vol .1, 2016.

\footnotetext{
${ }^{7}$ Ibid.
} 
Najih, Mokhammad dan Soimin, Pengantar Hukum Indonesia: Sejarah, Konsep Tata Hukum dan Politik Hukum Indonesia, Malang: Setara Press, 2012.

Pieris, John, Kecerdasan Hukum Respons Revolusi Industri 4.0, http://www.stagingpoint.com/read/2018/11/14/151205/Kecerdasan.Hukum. Respons.Revolusi.Industri.4.0.

Suradi, Pembangunan Manusia, Kemiskinan Dan Kesejahteraan Sosial Kajian tentang Kebijakan Pembangunan Kesejahteraan Sosial di Nusa Tenggara Barat, Jurnal Penelitian dan Pengembangan Kesejahteraan Sosial, Vol 12, No. 03, 2007. 